\author{
NINA NAWROT ${ }^{1}$
}

\title{
Sprawozdanie
}

\section{Ogólnopolska Konferencja Prawno-Medyczna Bezpieczeństwo Pacjentów i Personelu Medycznego Rzeszów, 4-5 grudnia 2018 roku}

Na początku grudnia 2018 roku odbyła się doroczna konferencja prawno-medyczna organizowana tym razem na Uniwersytecie Rzeszowskim przez Elsę Rzeszów. Tematem konferencji była ochrona praw pacjentów i personelu medycznego, a wzięli w niej udział specjaliści nauk prawnych i medycznych z kraju i z zagranicy. W ramach czterech paneli tematycznych dyskutowano o bezpieczeństwie pacjentów, bezpieczeństwie personelu medycznego, psychiatrii i leczeniu uzależnień oraz e-zdrowiu.

Pierwszego dnia konferencji znakomici prelegenci, w tym prof. UAM dr hab. J. Haberko, prof. UŁ dr hab. R. Kubiak, doc. JUDr F. Krepelka Ph.D. z Uniwersytetu Masaryka w Brnie, dr A. Wojtczyk, mec. W. Krawiec, przybliżyli m.in. problematykę zobowiązania zawieranego między pacjentem i lekarzem - w przypadku niewyleczenia pacjenta, kwestie prawne związane z bezpieczeństwem osób biorących w eksperymencie medycznym, a także te dotyczące bezpieczeństwa zarówno pacjentów, jak i zespołów ratownictwa medycznego w trakcie wykonywania czynności ratunkowych. Przedstawione zostały także prawne aspekty ochrony tzw. specjalnych kategorii danych osobowych - w odniesieniu do danych medycznych, a na zakończenie pierwszego dnia konferencji - problematyka marketingu produktów farmaceutycznych.

Drugiego dnia konferencji miała miejsce ciekawa dyskusja panelowa dotycząca najczęstszych problemów prawnych pojawiających się w praktyce lekarskiej. Brali w niej udział prokurator okręgowy w Rzeszowie Ł. Harpula oraz jego zastępca prok. A. Terlecki, a także dziekan Okręgowej Izby Radców Prawnych w Rzeszowie

$1 \quad$ Nina Nawrot - studentka II roku prawa w Akademii Leona Koźmińskiego; e-mail: 39271@ kozminski.edu.pl; ORCID: 0000-0002-9652-2553. 
r. pr. B. Opaliński oraz prezes Okręgowej Izby Lekarskiej w Rzeszowie - dr n. med. Wojciech Domka.

Kolejne tematy drugiego dnia konferencji poruszane przez prelegentów, wśród których byli m.in. dr. hab. F. Ciepły z KUL i dr A. Jacek z Uniwersytetu Rzeszowskiego, dotyczyły m.in. problematyki błędów medycznych, bezpieczeństwa personelu medycznego w związku z kwalifikowaniem pacjentów do szczepień, kwestii zgody pacjenta na leczenie oraz prawnych aspektów przymusowego leczenia uzależnień.

Na konferencji poruszane były też kwestie dotyczące szeroko pojętego e-zdrowia. Prelegenci, a wśród nich m.in. dr A. Fiutak z Uniwersytetu SWPS w Warszawie oraz dr E. Rabiej z Uniwersytetu Rzeszowskiego, przedstawili podstawowe problemy związane z zabezpieczeniem praw pacjenta korzystającego ze świadczeń zdrowotnych z wykorzystywaniem telemedycyny, w tym zabezpieczenia danych medycznych w związku z cyfryzacją sektora ochrony zdrowia.

Referaty przedstawione na konferencji wskazywały na konieczność dokonania wielu zmian w obowiązującym prawie, które w omawianych obszarach często jest nieprecyzyjne, a co za tym idzie - możliwe do elastycznej interpretacji, która nie powinna mieć miejsca tam, gdzie w grę wchodzi ludzkie zdrowie i życie. 